\title{
Elevated lipoprotein(a) and risk of coronary heart disease according to different lipid profiles in the general Chinese community population: the $\mathrm{CHCN}-\mathrm{BTH}$ study
}

\author{
Yong $\mathrm{Hu}^{1} \wedge$, Yong-Ming $\mathrm{He}^{2}$ \\ ${ }^{1}$ Division of Cardiology, 903 Hospital, Jiangyou, China; ${ }^{2}$ Division of Cardiology, the First Affiliated Hospital of Soochow University, Suzhou, China \\ Correspondence to: Yong-Ming He. Division of Cardiology, the First Affiliated Hospital of Soochow University, 188 Shizi Ave., Gusu District, Suzhou, \\ China. Email: heyongming@suda.edu.cn. \\ Response to: Guo C, Cao H, Shan G, et al. Elevated lipoprotein(a) and risk of coronary heart disease according to different lipid profiles in the general \\ Chinese community population: the CHCN-BTH study. Ann Transl Med 2021;9:26.
}

Submitted Feb 13, 2021. Accepted for publication Apr 11, 2021.

doi: 10.21037/atm-21-721

View this article at: http://dx.doi.org/10.21037/atm-21-721

We read with great interest the article by Guo et al. (1). This study has demonstrated that lipoprotein(a) [Lp(a)] is significantly associated with the risk of coronary heart disease in a dose-responding manner. Subgroup analysis has not altered this association. Our prior cross-sectional study has a similar finding with respect to $L p(a)$ 's role played in incidence of coronary artery disease (2). However, the study method regarding the synergistic effects between $L p(a)$ and dyslipidemia should be reconsidered. Assume that risk A for a disease is 1.10 and that risk $\mathrm{B}$ for the same disease is 1.21 , and coexistent risk $\mathrm{A}$ and $\mathrm{B}$ for the disease may be greater, equal or less than $1.10+1.21$. If coexistent risk $\mathrm{A}$ and $\mathrm{B}$ for the disease is 1.50 (greater than the sum of the separate effect), the synergistic effect (1.50-1.31), measured by Relative excess risk due to interaction (RERI) (3), occures. Our previous studies have demonstrated that the $\mathrm{Lp}$ (a) has a synergistic effect with low density lipoprotein cholesterol (LDL-C) or body mass index on the incidence of coronary artery disease $(4,5)$.

\section{Acknowledgments}

Funding: None.

\section{Footnote}

Provenance and Peer Review: This article was a standard submission to the journal. The article did not undergo external peer review.

Conflicts of Interest: Both authors have completed the ICMJE uniform disclosure form (available at http://dx.doi. org/10.21037/atm-21-721). YMH serves as an unpaid editorial board member of Annals of Translational Medicine from Oct 2019 to Sep 2021. The other author has no conflicts of interest to declare.

Ethical Statement: The authors are accountable for all aspects of the work in ensuring that questions related to the accuracy or integrity of any part of the work are appropriately investigated and resolved.

Open Access Statement: This is an Open Access article distributed in accordance with the Creative Commons Attribution-NonCommercial-NoDerivs 4.0 International License (CC BY-NC-ND 4.0), which permits the noncommercial replication and distribution of the article with the strict proviso that no changes or edits are made and

^ ORCID: 0000-0003-3572-5071. 


\section{Page 2 of 2}

the original work is properly cited (including links to both the formal publication through the relevant DOI and the license). See: https://creativecommons.org/licenses/by-ncnd/4.0/.

\section{References}

1. Guo C, Cao H, Shan G, et al. Elevated lipoprotein(a) and risk of coronary heart disease according to different lipid profiles in the general Chinese community population: the CHCN-BTH study. Ann Transl Med 2021;9:26.

2 Cai DP, He YM, Yang XJ, et al. Lipoprotein (a) is a risk factor for coronary artery disease in Chinese Han ethnic population modified by some traditional risk factors: A

Cite this article as: Hu Y, He YM. Elevated lipoprotein(a) and risk of coronary heart disease according to different lipid profiles in the general Chinese community population: the CHCN-BTH study. Ann Transl Med 2021;9(12):1030. doi: 10.21037/atm-21-721

\section{Hu and He. Synergistic effects between Lp(a) \& dyslipidemia}

cross-sectional study of 3462 cases and 6125 controls. Clin Chim Acta 2015;451:278-86.

3 Andersson T, Alfredsson L, Källberg H, et al. Calculating measures of biological interaction. Eur J Epidemiol 2005;20:575-9.

4 Teng RL, Wang H, Sun BC, et al. Interaction between lipoprotein (a) levels and body mass index in first incident acute myocardial infarction. BMC Cardiovasc Disord 2020;20:350.

$5 \mathrm{Hu}$ Y, Tao JY, Cai DP, et al. Interaction of lipoprotein(a) with low-density lipoprotein cholesterol on first incident acute myocardial infarction. Clin Chim Acta 2020;501:1-5. 